Artikel Penelitian

\title{
Variasi Diameter Kolom dan Rasio Sampel-Silika pada Isolasi Steroid dan Triterpenoid Alga Merah Eucheuma cottonii dengan Kromatografi Kolom Basah
}

\author{
Ahmad Ghanaim Fasya*, Ariska Purwaning Tyas, Fitroh Annisaul Mubarokah, Rachmawati Ningsih, \\ Armeida Dwi Ridhowati Madjid
}

Jurusan Kimia, Fakultas Sains dan Teknologi, Universitas Islam Negeri Maulana Malik Ibrahim, Malang, Indonesia, 65144

\section{INFO ARTIKEL}

\section{Riwayat Artikel}

Direvisi 28 September 2018

Diterima 15 Oktober 2018

Tersedia online 30 Desember 2018

* Email penulis korespondensi:

fasya.organik@kim.uin-malang.ac.id

\section{ABSTRAK}

Optimizing of steroids and triterpenes isolation from red algae Eucheuma cottonii was done using column chromatography by varying of column diameter $(1,1.5$ and $2 \mathrm{~cm})$ and a ratio of sample : silica $(1: 50,1: 100$, and 1:150). Active compound of $E$. cottonii was extracted by maceration with methanol. Then, the extract was hydrolyzed using $\mathrm{HCl} 2 \mathrm{~N}$ and partitioned with petroleum ether. The extract after partitioned was separated using wet column chromatography. The result of separation was monitored using analytical thin layer chromatography (Analytical TLC) and identified using fourier-transform infrared (FTIR). The best separation was aimed using diameter column $1 \mathrm{~cm}$ and a ratio of sample : silica 1:150. Based on FTIR analysis, the petroleum ether fraction from extract had a functional group $-\mathrm{OH},-\mathrm{C}-\mathrm{H}, \mathrm{C}=\mathrm{O},-\mathrm{C}\left(\mathrm{CH}_{3}\right)_{2}$, and $\mathrm{C}-\mathrm{OH}$ alcohol and the triterpenoid from extract had a functional group $-\mathrm{OH}, \mathrm{C}-\mathrm{H}, \mathrm{C}=\mathrm{O}, \mathrm{C}=\mathrm{C}$, $\mathrm{C}\left(\mathrm{CH}_{3}\right)_{2}$ and $\mathrm{C}-\mathrm{OH}$ alcohol.

Keywords: E. cottonii, column chromatography, steroid, triterpenoid, column size, sample : gel silica ratio

Optimasi isolasi senyawa steroid dan triterpenoid dalam alga merah Euchema cottonii telah dilakukan menggunakan kromatografi kolom dengan variasi diameter kolom $(1 ; 1,5$; dan $2 \mathrm{~cm})$ dan rasio sampel : silika (1:50; 1:100; dan $1: 150)$. Ekstraksi senyawa aktif pada $E$. cottonii dilakukan dengan maserasi menggunakan pelarut metanol. Ekstrak pekat metanol dihidrolisis menggunakan $\mathrm{HCl} 2 \mathrm{~N}$ dan dipartisi dengan petroleum eter. Hasil pemisahan dimonitoring menggunakan kromatografi lapis tipis analitik (KLTA) dan diidentifikasi menggunakan fourier-transform infrared (FTIR). Hasil penelitian menunjukkan pemisahan kromatografi kolom terbaik diperoleh dengan diameter kolom $1 \mathrm{~cm}$ dan rasio sampel : silika sebesar 1:150. Berdasarkan analisis FTIR, fraksi petroleum eter memberikan informasi gugus $-\mathrm{OH},-\mathrm{C}-\mathrm{H}, \mathrm{C}=\mathrm{O},-\mathrm{C}\left(\mathrm{CH}_{3}\right)_{2}$, dan $\mathrm{C}$ $\mathrm{OH}$ alkohol, sedangkan senyawa triterpenoid memberikan informasi gugus $-\mathrm{OH}$, $-\mathrm{C}-\mathrm{H}, \mathrm{C}=\mathrm{O}, \mathrm{C}=\mathrm{C},-\mathrm{C}\left(\mathrm{CH}_{3}\right)_{2}$ dan $\mathrm{C}-\mathrm{OH}$ alkohol.

Kata Kunci: E. cottonii, kromatografi kolom, steroid, triterpenoid, ukuran kolom, rasio sampel : silika gel 


\section{Pendahuluan}

Alga merah merupakan salah satu jenis tanaman perairan yang mengandung berbagai jenis zat-zat yang bermanfaat. Salah satu jenis alga yang mengandung banyak manfaat adalah Eucheuma cottonii. E. cottonii digunakan sebagai makanan alternatif untuk terapi kanker payudara [1], antitumor dan antimikroba [2]. Alga merah ini memiliki banyak manfaat karena mengandung banyak senyawa metabolit sekunder diantaranya steroid dan triterpenoid [2]. Steroid sendiri memiliki banyak manfaat yaitu sebagai penghambat kanker prostat [3], antimikroba [4], antiinflamasi dan agen analgesik [5]. Triterpenoid digunakan untuk mengobati diabetes, gangguan menstruasi, gangguan kulit, antimalaria dan antitumor [6]. Dari banyaknya manfaat yang terkandung dalam senyawa steroid dan triterpenoid, penting untuk dilakukan isolasi terhadap senyawa metabolit sekunder tersebut dari alga merah.

Isolasi senyawa metabolit sekunder secara umum dilakukan dengan metode ekstraksi maserasi yang dilanjutkan dengan hidrolisis untuk memutuskan ikatan glikosida antara glikon (gugus gula) dan aglikon (senyawa metabolit sekunder). Untuk mendapatkan senyawa metabolit sekunder yang terpisah dari glikon, keduanya dipisahkan dengan partisi. Hasil dari proses partisi biasanya masih dalam bentuk campuran. Untuk memisahkan dan mendapatkan senyawa metabolit sekunder yang lebih murni dapat dilakukan isolasi dengan menggunakan kromatografi kolom.

Kromatografi kolom merupakan metode pemisahan preparatif yang dapat menghasilkan isolat dalam jumlah yang cukup besar. Efisiensi pemisahan menggunakan kromatografi kolom dipengaruhi oleh adsorben, eluen, diameter kolom dan laju alir [7]. Adsorben berperan penting sebagai fase diam dari suatu kolom kromatografi sebagaimana pengaruhnya dalam efisiensi pemisahan yang berkaitan dengan teori plate dan teori kelajuan [8]. Pemisahan yang efisien menggunakan kromatografi kolom dapat dilakukan salah satunya dengan cara memperkecil jumlah sampel dalam proses elusi serta memperpanjang kolom (adsorben) [9]. Menurut Kondeti dkk. [10], ukuran diameter kolom dapat mempengaruhi keefisiensian pemisahan dalam kolom, dimana semakin tinggi fase diam yang dihasilkan maka semakin baik hasil pemisahannya. Efisiensi pemisahan dapat diketahui dengan nilai resolusi. Nilai resolusi yang tinggi menunjukkan kesempurnaan keterpisahan antar senyawa dalam campuran [9]. Pada penelitiaan ini akan dilakukan optimasi pemisahan hasil isolasi alga merah dengan memvariasi diameter kolom $(1,0 ; 1,5 ;$ dan $2 \mathrm{~cm})$ serta variasi rasio sampel : silika (1:50, 1:100, 1:150). Monitoring hasil pemisahan dilakukan menggunakan kromatografi lapis tipis (KLT) dan identifikasi hasil pemisahan dilakukan menggunakan fourier-transform infrared (FTIR).

\section{Bahan dan Metode}

\subsection{Bahan}

Bahan utama dalam penelitian ini adalah alga merah Eucheuma cottonii dari Wongsorejo Banyuwangi. Bahan kimia yang digunakan adalah metanol (Merck), $\mathrm{HCl} 2 \mathrm{~N}$ (Merck), petroleum eter (Merck), n-heksana merck, etil asetat (Merck), asam asetat anhidrat (Merck), $\mathrm{H}_{2} \mathrm{SO}_{4}$ pekat (Merck), kloroform (Merck), plat silika gel $\mathrm{GF}_{254}$ (Merck) dan silika gel 60.

\subsection{Preparasi dan Ekstraksi Sampel}

Alga merah dicuci bersih, kemudian dipotong kecil-kecil, dan dikeringanginkan lalu dioven pada suhu $38^{\circ} \mathrm{C}$ selama 24 jam. Sampel yang sudah kering dihaluskan hingga didapatkan serbuk alga merah. Sampel alga merah sebanyak 100 g diekstraksi secara maserasi menggunakan $500 \mathrm{~mL}$ pelarut metanol selama 24 jam disertai dengan pengocokan, dan kemudian disaring. Ampas yang diperoleh selanjutnya dimaserasi kembali dengan menggunakan pelarut yang sama. Filtrat yang diperoleh dipekatkan menggunakan rotary evaporator.

Ekstrak pekat metanol alga merah dihidrolisis dengan ditambahkan $\mathrm{HCl} 2 \mathrm{~N}$ dan diaduk dengan bantuan magnetic stirer pada suhu ruang selama 1 jam. Hidrolisat yang diperoleh ditambahkan $\mathrm{NaHCO}_{3}$ sampai $\mathrm{pH}$ netral $(\mathrm{pH} 7)$. Hidrolisat dengan $\mathrm{pH} 7$ kemudian dipartisi dengan petroleum eter : metanol (50:50), dan diambil fasa organiknya. Ekstrak hasil partisi kemudian dipekatkan dengan rotary evaporator sehingga diperoleh ekstrak pekat yang kemudian ditimbang beratnya dan ditentukan rendemennya [11].

\subsection{Penentuan Kadar Air}

Serbuk sampel sebanyak $1 \mathrm{~g}$ dimasukkan dalam cawan porselen yang sudah diketahui berat konstannya, kemudian dioven pada suhu $100-105^{\circ} \mathrm{C}$ dan didinginkan dalam desikator. Perlakuan ini diulangi sampai berat konstan. Kadar air dalam alga merah dapat dihitung menggunakan Persamaan 1 [12].

$$
\text { Kadar air }=\frac{(B-C)}{(B-A)} \times 100 \%
$$


Dimana $A=$ bobot cawan kosong, $B=$ bobot sampel + cawan sebelum dikeringkan, dan $C=$ bobot cawan + sampel setelah dikeringkan.

\subsection{Uji Steroid dengan Lieberman Burchard}

Sebanyak $5 \mathrm{mg}$ ekstrak petroleum eter alga merah dilarutkan dalam kloroform, lalu ditambahkan asam asetat anhidrida dan $\mathrm{H}_{2} \mathrm{SO}_{4}$ pekat melalui dinding tabung. Jika terbentuk warna hijau kebiruan menunjukkan adanya golongan senyawa steroid dan Jika terbentuk cincin kecoklatan atau violet pada pembatas dua pelarut menunjukkan adanya golongan senyawa triterpenoid.

\subsection{Isolasi Steroid dengan Kromatografi Kolom}

\subsubsection{Isolasi Steroid dan Triterpenoid dengan Variasi Diameter Kolom}

Proses Isolasi menggunakan kromatografi kolom basah dengan fase diam silika gel 60 dan fase gerak berupa nheksana : etil asetat $(4,25: 0,25)$. Bubur silika dibuat dengan cara merendam silika sebanyak 10 gram dengan eluen kemudian dimasukkan ke dalam kolom dan didiamkan selama 24 jam [13]. Setelah itu, 0,1 g sampel dimasukkan dalam kolom berdiameter $1 \mathrm{~cm}$. Perlakuan yang sama diulangi untuk diameter kolom dengan 1,5 dan $2 \mathrm{~cm}$. Kecepatan alir diatur $2 \mathrm{~mL} /$ menit dan proses elusi dilakukan hingga vial ke 200 .

\subsubsection{Isolasi Steroid dan Triterpenoid dengan Variasi Rasio Sampel dan Silika gel}

Persiapan kolom dilakukan prosedur yang sama seperti pada tahapan 2.5.1. Kemudian, sampel diambil sesuai variasi dalam kolom $A, B$, dan $C$ dengan ditimbang 0,$067 ; 0,1 ; 0,2 \mathrm{~g}$ (perbandingan rasio sampel dengan silika gel 1:150; 1:100; 1:50). Eluat ditampung pada botol vial tiap $2 \mathrm{~mL}$.

\subsection{Monitoring dengan Kromatografi Lapis Tipis Analitik}

Identifikasi fraksi hasil isolasi kromatografi kolom dilakukan dengan kromatografi lapis tipis analitik (KLTA). Fase diam yang digunakan plat silika gel $\mathrm{GF}_{254}$ dan eluen sebagai fase gerak berupa pelarut campuran $\mathrm{n}$-heksana dan etil asetat dengan perbandingan 4,25:0,75. Fraksi ditotolkan pada plat silika gel yang telah diaktivasi dan dimasukkan ke dalam bejana pengembang yang berisikan eluen yang sudah dijenuhkan dan dielusi sampai tanda batas atas. Noda/bercak hasil pemisahan kemudian diamati di bawah sinar UV $(254 \mathrm{~nm})$ dan dihitung Rf (retention factor) serta resolusinya (Rs). Resolusi pemisahan ditentukan menggunakan Persamaan 2.

$$
\text { Resolusi }=\frac{d}{\left(W_{1}+W_{2}\right) \times 0,5}
$$

Dimana, $\mathrm{d}=$ jarak antar 2 pusat noda, $\mathrm{W}_{1}$ dan $\mathrm{W}_{2}=$ rata-rata lebar noda.

\subsection{Identifikasi Gugus Fungsi dengan Spektrofotometer FTIR}

Senyawa hasil isolasi diidentifikasi dengan menggunakan spektrofotometer FTIR. Isolat yang diperoleh dijadikan pelet $\mathrm{KBr}$ dan dipress dengan tekanan 80 Torr. Sampel yang sudah berupa pelet dimasukkan ke dalam spektrofotometer FTIR untuk dianalisis gugus fungsi pada spektra yang dihasilkan.

\section{Hasil dan Pembahasan}

\subsection{Preparasi dan Ekstraksi Sampel}

Sampel dikeringanginkan untuk menghilangkan kadar air dalam sampel. Sampel yang telah kering dihaluskan. Hasilnya sampel dalam bentuk serbuk untuk dimaserasi. Kemudian serbuk alga merah dianalisis kadar airnya untuk mengetahui kandungan air dalam sampel tersebut. Kandungan kadar air pada sampel alga merah sebesar $5,41 \%$ yang memenuhi syarat untuk maserasi yaitu kadar air maksimal <11\% [15]. Rendemen ekstraksi alga merah menggunakan metode maserasi dengan pelarut metanol diperoleh sebesar 15,59\%. Ekstrak metanol tersebut yang selanjutnya dihidrolisis dengan katalis asam $(\mathrm{HCl} 2 \mathrm{~N})$ untuk memutus ikatan antara glikon dengan aglikon (metabolit sekunder). Pemisahan metabolit sekunder (aglikon) yang sudah terputus ikatannya pada proses hidrolisis dilakukan dengan menggunakan campuran petroleum eter dan metanol menghasilkan dua lapisan, yaitu fase organik dan air. Bagian aglikon (metabolit skeunder) akan terdistribusi dalam petroleum eter (fase organik) sedangkan yang lainnya ke fasa air. Fasa organik yang didapatkan dipisahkan dari pelarutnya dengan menggunakan rotary evaporator vacuum. Rendemen yang diperoleh pada tahapan partisi sebesar $9,25 \%$. 


\subsection{Uji Steroid dengan Lieberman Burchard}

Ekstrak pekat petroleum eter yang dilarutkan dengan reagen Lieberman Burchard menghasilkan warna hijau yang menunjukkan senyawa steroid dan adanya cincin coklat menunjukkan senyawa triterpenoid.

\subsection{Isolasi Steroid dan Triterpenoid dengan Variasi Diameter Kolom}

Berdasarkan hasil monitoring pada Tabel 1, 2 dan 3 dapat diketahui bahwa kolom dengan diameter $1 \mathrm{~cm}$ merupakan variasi diameter kolom terbaik fraksi tunggal terbanyak yaitu satu steroid dan dua triterpenoid dengan resolusi yaitu Rs = 1,650; Rs = 0,825 dan Rs $=0,990$. Dengan jumlah fasa diam (silika) yang sama yaitu 10 gram maka pada kolom diameter $1 \mathrm{~cm}$, tinggi fasa diamnya adalah yang paling tinggi jika dibandingkan dengan kolom dengan diameter yang lebih besar $(1,5$ dan $2 \mathrm{~cm}$ ). Sesuai dengan teori kromatografi pada teori piringan, yaitu $\mathrm{H}=\mathrm{L} / \mathrm{N}$ dimana $\mathrm{H}$ adalah tinggi piringan teoritis yang menyatakan efisiensi pemisahan, $\mathrm{L}$ adalah panjang kolom dan $\mathrm{N}$ adalah jumlah piringan, maka dengan fasa diam yang sama maka tinggi $\mathrm{H}$ untuk tiap-tiap kolom adalah sama tetapi karena kolom dengan $\mathrm{d}=1$ $\mathrm{cm}$ lebih tinggi maka jumlah piringan yang dimiliki akan semakin banyak dan pemisahan menjadi lebih baik (jumlah fraksi tunggal yang dihasilkan dan resolusi lebih baik).

Tabel 1. Hasil Monitoring Diameter Kolom $2 \mathrm{~cm}$

\begin{tabular}{|c|c|c|c|c|}
\hline Fraksi & Warna & Senyawa & $\begin{array}{c}\text { Retention Factor } \\
\text { (Rf) }\end{array}$ & Resolusi \\
\hline $1-7$ & - & - & - & - \\
\hline $8-9$ & Hijau & Steroid & 0,688 & 1,060 \\
\hline $10-14$ & $\begin{array}{l}\text { Hijau } \\
\text { Merah }\end{array}$ & $\begin{array}{c}\text { Steroid } \\
\text { Triterpenoid }\end{array}$ & $\begin{array}{l}0,669 \\
0,475\end{array}$ & 1,060 \\
\hline $15-22$ & $\begin{array}{l}\text { Hijau } \\
\text { Ungu }\end{array}$ & $\begin{array}{c}\text { Steroid } \\
\text { Triterpenoid }\end{array}$ & $\begin{array}{l}0,388 \\
0,388\end{array}$ & 0,353 \\
\hline $23-31$ & $\begin{array}{l}\text { Hijau } \\
\text { Ungu } \\
\text { Merah }\end{array}$ & $\begin{array}{c}\text { Steroid } \\
\text { Triterpenoid } \\
\text { Triterpenoid } \\
\end{array}$ & $\begin{array}{l}0,388 \\
0,388 \\
0,225 \\
\end{array}$ & $\begin{array}{l}0,353 \\
0,795\end{array}$ \\
\hline $32-42$ & $\begin{array}{l}\text { Hijau } \\
\text { Ungu } \\
\text { Merah }\end{array}$ & $\begin{array}{c}\text { Steroid } \\
\text { Triterpenoid } \\
\text { Triterpenoid }\end{array}$ & $\begin{array}{l}0,388 \\
0,388 \\
0,238\end{array}$ & $\begin{array}{l}0,353 \\
0,795\end{array}$ \\
\hline $43-90$ & $\begin{array}{l}\text { Merah } \\
\text { Merah } \\
\text { Merah }\end{array}$ & $\begin{array}{l}\text { Triterpenoid } \\
\text { Triterpenoid } \\
\text { Triterpenoid }\end{array}$ & $\begin{array}{l}0,150 \\
0,225 \\
0,150\end{array}$ & 0,533 \\
\hline $91-125$ & Merah & Triterpenoid & 0,144 & 0,533 \\
\hline
\end{tabular}

Tabel 2. Hasil Monitoring Diameter Kolom $1,5 \mathrm{~cm}$

\begin{tabular}{|c|c|c|c|c|}
\hline Fraksi & Warna & Senyawa & $\begin{array}{c}\text { Retention Factor } \\
\text { (Rf) }\end{array}$ & Resolus \\
\hline $1-8$ & - & - & - & - \\
\hline $9-10$ & Hijau & Steroid & 0,656 & 1,100 \\
\hline $11-12$ & $\begin{array}{l}\text { Hijau } \\
\text { Merah }\end{array}$ & $\begin{array}{c}\text { Steroid } \\
\text { Triterpenoid }\end{array}$ & $\begin{array}{l}0,650 \\
0,469\end{array}$ & 1,100 \\
\hline $13-16$ & Merah & Triterpenoid & 0,475 & 0,530 \\
\hline $17-19$ & $\begin{array}{l}\text { Merah } \\
\text { Hijau } \\
\text { Ungu }\end{array}$ & $\begin{array}{l}\text { Triterpenoid } \\
\text { Steroid } \\
\text { Triterpenoid }\end{array}$ & $\begin{array}{l}1,283 \\
0,394 \\
0,338\end{array}$ & $\begin{array}{l}0,530 \\
0,404\end{array}$ \\
\hline $20-29$ & $\begin{array}{l}\text { Hijau } \\
\text { Ungu }\end{array}$ & $\begin{array}{c}\text { Steroid } \\
\text { Triterpenoid }\end{array}$ & $\begin{array}{l}0,388 \\
0,338\end{array}$ & 0,404 \\
\hline $30-37$ & $\begin{array}{l}\text { Hijau } \\
\text { Ungu }\end{array}$ & $\begin{array}{c}\text { Steroid } \\
\text { Triterpenoid }\end{array}$ & $\begin{array}{l}0,400 \\
0,225\end{array}$ & 0,636 \\
\hline $38-39$ & - & - & - & - \\
\hline $40-67$ & $\begin{array}{l}\text { Merah } \\
\text { Merah }\end{array}$ & $\begin{array}{l}\text { Triterpenoid } \\
\text { Triterpenoid }\end{array}$ & $\begin{array}{l}0,225 \\
0,144\end{array}$ & 0,441 \\
\hline $68-90$ & Merah & Triterpenoid & 0,150 & 0,441 \\
\hline
\end{tabular}


Fasya dkk. / ALCHEMY: JOURNAL OF CHEMISTRY, 6 : 2 (2018) 57-64

Tabel 3. Hasil Monitoring Diameter Kolom $1 \mathrm{~cm}$

\begin{tabular}{|c|c|c|c|c|}
\hline Fraksi & Warna & Senyawa & $\begin{array}{c}\text { Retention Factor } \\
\text { (Rf) }\end{array}$ & Resolusi \\
\hline $1-7$ & - & - & - & - \\
\hline 8 & Hijau & Steroid & 0,669 & 1,650 \\
\hline $9-11$ & $\begin{array}{l}\text { Hijau } \\
\text { Merah }\end{array}$ & $\begin{array}{c}\text { Steroid } \\
\text { Triterpenoid }\end{array}$ & $\begin{array}{l}0,663 \\
0,488\end{array}$ & 1,650 \\
\hline $12-13$ & Merah & Triterpenoid & 0,488 & 0,825 \\
\hline $14-16$ & $\begin{array}{c}\text { Merah } \\
\text { Hijau }\end{array}$ & $\begin{array}{c}\text { Triterpenoid } \\
\text { Steroid }\end{array}$ & $\begin{array}{l}0,488 \\
0,388\end{array}$ & 0,825 \\
\hline $17-24$ & $\begin{array}{l}\text { Ungu } \\
\text { Hijau }\end{array}$ & $\begin{array}{c}\text { Triterpenoid } \\
\text { Steroid }\end{array}$ & $\begin{array}{l}0,350 \\
0,388\end{array}$ & 0,471 \\
\hline 25 & $\begin{array}{l}\text { Ungu } \\
\text { Hijau } \\
\text { Ungu } \\
\text { Merah }\end{array}$ & $\begin{array}{l}\text { Triterpenoid } \\
\text { Steroid } \\
\text { Triterpenoid } \\
\text { Triterpenoid }\end{array}$ & $\begin{array}{l}0,350 \\
0,393 \\
0,356 \\
0,238\end{array}$ & $\begin{array}{l}0,471 \\
1,296\end{array}$ \\
\hline $26-31$ & $\begin{array}{l}\text { Hijau } \\
\text { Merah }\end{array}$ & $\begin{array}{c}\text { Steroid } \\
\text { Triterpenoid }\end{array}$ & $\begin{array}{l}0,413 \\
0,225 \\
\end{array}$ & 1,414 \\
\hline $32-33$ & $\begin{array}{l}\text { Hijau } \\
\text { Merah } \\
\text { Merah }\end{array}$ & $\begin{array}{c}\text { Steroid } \\
\text { Triterpenoid } \\
\text { Triterpenoid }\end{array}$ & $\begin{array}{l}0,400 \\
0,238 \\
0,161\end{array}$ & $\begin{array}{l}1,414 \\
0,707\end{array}$ \\
\hline $34-60$ & $\begin{array}{l}\text { Merah } \\
\text { Merah }\end{array}$ & $\begin{array}{l}\text { Triterpenoid } \\
\text { Triterpenoid }\end{array}$ & $\begin{array}{l}0,238 \\
0,161 \\
\end{array}$ & 0,990 \\
\hline $61-115$ & Merah & Triterpenoid & 0,163 & 0,990 \\
\hline
\end{tabular}

\subsection{Isolasi Steroid dan Triterpenoid dengan Kromatografi Kolom Basah Variasi Rasio Sampel dan Silika Gel}

Hasil monitoring variasi rasio sampel dan silika gel 1:50; 1:100; 1:150 ditunjukkan pada Tabel 4, 5 dan $\mathbf{6}$. Masingmasing variasi dikelompokkan berdasarkan nilai Rf dan warna noda. Hasil monitoring dengan noda tunggal dikelompokkan dan dihitung nilai resolusinya.

Tabel 4. Hasil monitoring variasi sampel : silika (1:50)

\begin{tabular}{|c|c|c|c|c|}
\hline Fraksi & Warna & Senyawa & $\begin{array}{l}\text { Retention Factor } \\
\text { (Rf) }\end{array}$ & Resolusi \\
\hline $1-9$ & - & - & - & - \\
\hline \multirow{2}{*}{10} & Hijau & \multirow{2}{*}{ Campuran } & 0,838 & \multirow{2}{*}{1,414} \\
\hline & Hijau & & 0,700 & \\
\hline $11-13$ & Hijau & Steroid & 0,700 & 1,414 \\
\hline \multirow{2}{*}{$14-15$} & Hijau & \multirow{2}{*}{ Campuran } & 0,706 & \multirow{2}{*}{1,149} \\
\hline & Merah & & 0,538 & \\
\hline $16-20$ & Merah & Triterpenoid & 0,544 & 0,618 \\
\hline \multirow{2}{*}{$21-24$} & Merah & \multirow{2}{*}{ Campuran } & 0,544 & \multirow{2}{*}{0,618} \\
\hline & Hijau & & 0,450 & \\
\hline \multirow{3}{*}{$25-35$} & Ungu & \multirow{3}{*}{ Campuran } & 0,388 & \multirow{3}{*}{$\begin{array}{l}0,618 \\
0,618\end{array}$} \\
\hline & Hijau & & 0,463 & \\
\hline & Ungu & & 0,400 & \\
\hline \multirow{2}{*}{$36-49$} & Hijau & \multirow{2}{*}{ Campuran } & 0,450 & \multirow{2}{*}{1,237} \\
\hline & Merah & & 0,269 & \\
\hline \multirow{2}{*}{$50-75$} & Merah & \multirow{2}{*}{ Campuran } & 0,263 & \multirow{2}{*}{0,618} \\
\hline & Merah & & 0,169 & \\
\hline $76-115$ & Merah & Triterpenoid & 0,169 & 0,618 \\
\hline $116-200$ & - & - & - & - \\
\hline
\end{tabular}

Hasil monitoring variasi rasio sampel dan silika gel 1:50 diperoleh tiga kelompok fraksi yaitu 1 fraksi steroid pada kelompok fraksi $11-13$ dan 2 fraksi triterpenoid pada fraksi $16-20$ dan $76-115$. Begitu pula dengan hasil monitoring variasi 1:100 yang mendapatkan jumlah fraksi noda tunggal yang sama dengan variasi 1:50, vial $9-10$ dengan fraksi steroid, dan 2 fraksi triterpenoid pada kelompok fraksi 13 - 16 dan 68 - 90. 
Fasya dkk. / ALCHEMY: JOURNAL OF CHEMISTRY, 6 : 2 (2018) 57-64

Tabel 5. Hasil monitoring variasi sampel : silika (1:100)

\begin{tabular}{|c|c|c|c|c|}
\hline Fraksi & Warna & Senyawa & $\begin{array}{c}\text { Retention Factor } \\
\text { (Rf) }\end{array}$ & Resolusi \\
\hline $1-8$ & - & - & - & - \\
\hline $9-10$ & Hijau & Steroid & 0,656 & 1,100 \\
\hline $11-12$ & $\begin{array}{l}\text { Hijau } \\
\text { Merah }\end{array}$ & Campuran & $\begin{array}{l}0,650 \\
0,469\end{array}$ & 1,100 \\
\hline $13-16$ & Merah & Triterpenoid & 0,475 & 1,100 \\
\hline $17-19$ & $\begin{array}{l}\text { Merah } \\
\text { Hijau } \\
\text { Ungu }\end{array}$ & Campuran & $\begin{array}{l}0,481 \\
0,394 \\
0,338\end{array}$ & $\begin{array}{l}0,530 \\
0,404\end{array}$ \\
\hline $20-29$ & $\begin{array}{l}\text { Hijau } \\
\text { Ungu }\end{array}$ & Campuran & $\begin{array}{l}0,388 \\
0,338\end{array}$ & 0,404 \\
\hline $30-37$ & $\begin{array}{l}\text { Hijau } \\
\text { Merah }\end{array}$ & Campuran & $\begin{array}{l}0,400 \\
0,225\end{array}$ & 0,636 \\
\hline $38-39$ & - & - & - & - \\
\hline $40-67$ & $\begin{array}{l}\text { Merah } \\
\text { Merah }\end{array}$ & Campuran & $\begin{array}{l}0,225 \\
0,144\end{array}$ & 0,441 \\
\hline $68-90$ & Merah & Triterpenoid & 0,150 & 0,441 \\
\hline $91-200$ & - & - & - & - \\
\hline
\end{tabular}

Hasil monitoring variasi rasio sampel dan silika gel 1:150 juga diperoleh tiga kelompok fraksi, 1 kelompok fraksi steroid dan 2 kelompok fraksi triterpenoid. Berdasarkan nilai resolusi dari spot-spot tunggal yang diindikasikan sebagai senyawa murni steroid dan triterpenoid ditunjukkan bahwa resolusi terbaik dari ketiga variasi ialah variasi 1:150 dengan nilai resolusi yang paling besar dibandingkan dengan variasi 1:50 dan 1:100. Nilai resolusi yang tinggi menunjukkan kesempurnaan keterpisahan antara dua buah puncak kromatogram dengan nilai Rs mendekati 1,5 atau lebih dari 1,5 memberikan hasil pemisahan 2 puncak yang sangat baik dan minim terjadinya tumpang tindih senyawa [9]. Dengan memperbesar rasio antara sampel dengan silika sebagai fasa diam maka sebenarnya adalah memperkecil jumlah sampel yang akan dianalisis. Dengan jumlah sampel yang lebih kecil maka terjadi transfer massa yang cukup untuk seluruh bagian sampel sehingga jarak antara satu senyawa yang satu dengan lainnya menjadi cukup baik dan tidak tumpang tindih. Hal tersebut terbukti bahwa pada dasarnya pada ketiga variasi dihaslkan jumlah fraksi tunggal yang sama yaitu 1 fraksi steroid dan 2 fraksi triterpen tetapi pada rasio 1:150 resolusinya menjadi lebih baik.

Tabel 6. Hasil monitoring variasi sampel : silika (1:150)

\begin{tabular}{|c|c|c|c|c|}
\hline Fraksi & Warna & Senyawa & $\begin{array}{c}\text { Retention Factor } \\
\text { (Rf) }\end{array}$ & Resolusi \\
\hline $1-9$ & - & - & - & - \\
\hline $10-11$ & Hijau & Steroid & 0,619 & 1,799 \\
\hline 12 & $\begin{array}{c}\text { Hijau } \\
\text { Merah }\end{array}$ & Campuran & $\begin{array}{l}0,613 \\
0,431\end{array}$ & 1,799 \\
\hline $13-16$ & Merah & Triterpenoid & 0,438 & 1,799 \\
\hline $17-26$ & $\begin{array}{l}\text { Hijau } \\
\text { Ungu }\end{array}$ & Campuran & $\begin{array}{l}0,350 \\
0,300\end{array}$ & 0,471 \\
\hline 27 & $\begin{array}{l}\text { Hijau } \\
\text { Ungu } \\
\text { Merah }\end{array}$ & Campuran & $\begin{array}{l}0,350 \\
0,313 \\
0,225\end{array}$ & $\begin{array}{l}0,471 \\
0,707\end{array}$ \\
\hline $28-42$ & $\begin{array}{l}\text { Hijau } \\
\text { Merah }\end{array}$ & Campuran & $\begin{array}{l}0,388 \\
0,213\end{array}$ & 1,590 \\
\hline $43-48$ & $\begin{array}{c}\text { Hijau } \\
\text { Merah } \\
\text { Merah }\end{array}$ & Campuran & $\begin{array}{l}0,363 \\
0,213 \\
0,138\end{array}$ & $\begin{array}{l}1,590 \\
0,707\end{array}$ \\
\hline $49-67$ & $\begin{array}{l}\text { Merah } \\
\text { Merah }\end{array}$ & Campuran & $\begin{array}{l}0,206 \\
0,131\end{array}$ & 0,707 \\
\hline $68-95$ & Merah & Triterpenoid & 0,125 & 0,707 \\
\hline $96-200$ & - & - & - & - \\
\hline
\end{tabular}


Hasil identifikasi menggunakan FTIR pada fraksi 10 - 11 menunjukkan adanya regang $\mathrm{C}-\mathrm{H}$ alifatik pada 2926,406 $\mathrm{cm}^{-1}$ yang dimungkinkan adanya gugus metil $\left(-\mathrm{CH}_{3}\right)$ [16]. Dugaan ini diperkuat dengan vibrasi $\mathrm{C}-\mathrm{H}$ stretch pada 1381,990 dan $1462,945 \mathrm{~cm}^{-1}$. Vibrasi gugus $\mathrm{C}=\mathrm{O}$ keton pada $1731,842 \mathrm{~cm}^{-1}$. Vibrasi $\mathrm{C}-\mathrm{H}$ stretch tersebut yang mengindikasikan adanya gugus geminal dimetil $\left(-\mathrm{C}\left(\mathrm{CH}_{3}\right)_{2}\right)$ yang lazim ditemukan pada senyawa steroid. Identifikasi gugus fungsi pada fraksi 12 - 16 menunjukkan adanya serapan gugus $-\mathrm{OH}, \mathrm{C}-\mathrm{OH}$ alkohol, vibrasi $\mathrm{C}-\mathrm{H}$ stretch atau geminal dimetil, $\mathrm{C}=\mathrm{O}$ asam karboksilat. Adapun fraksi 68 - 95 menunjukkan adanya serapan gugus $-\mathrm{OH}, \mathrm{C}-\mathrm{OH}$ alkohol, $\mathrm{C}-\mathrm{H}$ stretch atau geminal dimetil, $\mathrm{C}=\mathrm{C}$, gugus metil dan metilen. Berdasarkan serapan-serapan tersebut mengindikasikan kedua fraksi tersebut merupakan senyawa triterpenoid.

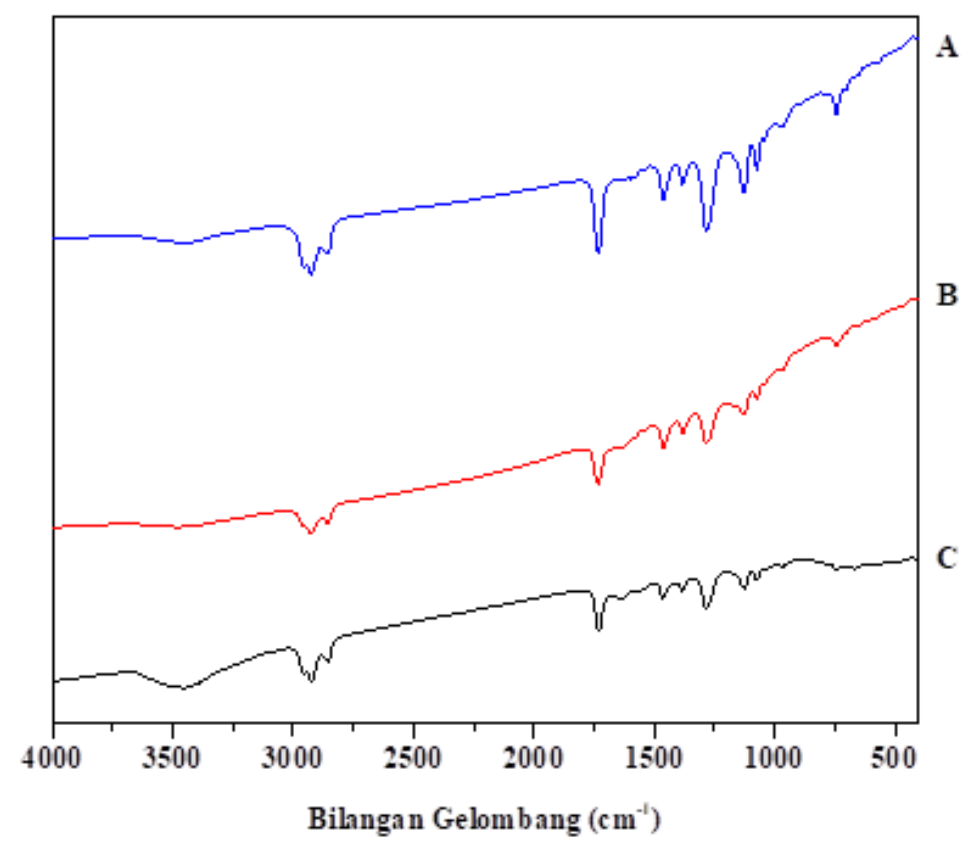

Gambar 1. Spektra hasil Identifikasi FTIR fraksi tunggal variasi 1:150 (A) fraksi 10 - 11 senyawa steroid, (B) fraksi 13 16 senyawa triterpenoid 1 dan $(C)$ fraksi 68 - 95 senyawa triterpenoid 2.

\section{Kesimpulan}

Hasil isolasi senyawa steroid dan triterpenoid pada fraksi petroleum eter alga merah terbaik diperoleh dengan variasi diameter $1 \mathrm{~cm}$ dan rasio sampel : silika terbaik adalah variasi 1:150. Jumlah senyawa yang diperoleh adalah 1 senyawa steroid dan 2 senyawa terpenoid.

\section{Ucapan Terima Kasih}

Penulis mengucapkan banyak terima kasih kepada Lembaga Penelitian Pengabdian Masyarakat (LP2M) UIN Maulana Malik Ibrahim Malang melalui dana bantuan penelitian pengembangan program studi 2018.

\section{Daftar Pustaka}

[1] F. Namvar, S., Mohamed, S. G. Fard, J. Behravan, N. M. Mustapha, N. B. M. Alitheen, \& F. Othman, "Polyphenolrich Seaweed (Eucheuma cottonii) Extract Suppresses Breast Tumour via Hormone Modulation and Apoptosis Induction," Food Chemistry, vol. 130, no. 2, pp. 376-382, 2012.

[2] S. Afif, "Uji Toksisitas dengan Metode BSLT (Brine Shrimp Lethality Test) dan Identifikasi Golongan Senyawa Aktif Ekstrak Alga Merah Eucheuma cottoni dari Perairan Sumenep Madura," Skripsi, Universitas Islam Negeri Maulana Malik Ibrahim, Malang, 2013.

[3] J. L. Zhang, H. Y. Tian, J. Li, L. Jin, C. Luo, W. C. Ye, \& R. W. Jiang, "Steroids with Inhibitory Activity against the Prostate Cancer Cells and Chemical Diversity of Marine Alga Tydemania expeditionis," Fitoterapia, vol. 83, no. 5, pp. $973-978,2012$.

[4] A. E. Farouk, A. H. G. Faizal, \& B. H. Ridzwan, "New Bacterial Species Isolated from Malaysian Sea Cucumbers with Optimized Secreted Antibacterial Activity," American Journal of Biochemistry and Biotechnology, vol. 3, no.2, pp. 64-69, 2007. 
[5] A. P. Singh, "Short Review: Distribution of Steroid like Compound in Plant Flora," Pharmacognosy Magazine, vol. 2, no. 6 , pp. 87-89, 2006.

[6] S. T. Lee, P. F. Wong, S. C. Cheah, \& M. R. Mustafa, "Alpha-tomatine Induces Apoptosis and Inhibits Nuclear Factor-kappa B Activation on Human Prostatic Adenocarcinoma PC-3 cells," PLoS One, vol. 6, no.4, 2011.

[7] A. V. Kristanti, N. S. Aminah, M. Tanjung, \& B. Kurniadi, Buku Ajar Fitokimia. Surabaya: Airlangga University Press, 2008.

[8] I. Sundari, "Identifikasi Senyawa dalam Ekstrak Etanol Biji Buah Merah (Pandanus conoideus Lamk.)," Skripsi, Universitas Sebelas Maret, Surakarta, 2010.

[9] S. Wonorahardjo, Metode-Metode Pemisahan Kimia: Sebuah Pengantar. Jakarta: Akademia, 2013.

[10] R. R. Kondeti, K. S. Mulpuri, \& B. Meruga, "Advancements in Column Chromatography: A Review," World Journal of Pharmaceutical Sciences, vol. 2, no. 10, pp. 1375-1383, 2014.

[11] I. M. Setiyawan, "Isolasi Senyawa Triterpenoid Fraksi Petroleum Eter Alga Merah (Eucheuma spinosum) Hasil Hidrolisis Ekstrak Metanol dan Identifikasinya Menggunakan FTIR," Skripsi, Universitas Islam Negeri Maulana Malik Ibrahim, Malang, 2015.

[12] AOAC, Official Methods of Analysis. Washington DC: Association of Official Analytical Chemists, 1984.

[13] A. N. L. Sholikah, "Isolasi Senyawa Steroid dari Fraksi Petroleum Eter Hasil Hidrolisis Ekstrak Metanol Alga Merah (Eucheuma spinosum) Menggunakan Metode Kromatografi Kolom," Skripsi, Universitas Islam Negeri Maulana Malik Ibrahim, Malang, 2016.

[14] Kusmiyati, N. Aznam, \& S. Handayani, "Isolasi dan Identifikasi Zat Aktif Ekstrak Metanol Rimpang Kunyit Putih (Curcuma mangga Val) Fraksi Etil Asetat," Jurnal IImiah Kefarmasian. vol. 1, no. 2, pp. 1-10, 2011.

[15] A. Sulistijowati \& D. Gunawan, "Efek Ekstrak Daun Kembang Bulan (Tithonia diversifolia A. Gray) terhadap Candica albicans serta Profil Kromatografinya," Media Penelitian dan Pengembangan Kesehatan, vol. 8, no. 3, pp. 32-37, 1998.

[16] G. Socrates, Infrared Characteristic Group Frequencies $2^{\text {nd }}$ Edition. England: John Wiley and Sons Ltd, 1994. 